\title{
Hebrew Proficiency Certification According to the Common EUROPEAN FrameWORK OF REFERENCE FOR LANGUAGES - An Educational Challenge
}

\author{
Angelika Adamczyk \\ https://orcid.org/0000-0003-3321-9693 \\ (University of Warsaw) \\ e-mail: aadamczyk@uw.edu.pl
}

Keywords: Hebrew instruction, certification, language assessment, language teaching methodology, CEFRL, communicative approach

\begin{abstract}
The necessity of creating new curricula for teaching foreign languages (including Hebrew) and adjusting them to the requirements of the Common European Framework of Reference for Languages (CEFRL) is a result of implementing the Bologna Process in the Polish system of higher education. The whole approach to teaching Hebrew to Polish students, as well as methods of assessment, had to be changed according to the new requirements.

In this paper, I wish to study some challenges and difficulties which might be faced by Hebrew instructors in Europe and by the authors of Hebrew certificate exams.

First, I will present the main assumptions of CEFRL and its certification system. Then, I will compare it with the Hebrew language curriculum and methods of assessment, as developed and applied in ulpanim (Hebrew language schools) in Israel. Next, I will present some challenges which might be faced by teachers preparing course participants to pass their certificate exams at appropriate levels, adjusting the curriculum's goals to the assumptions of the CEFRL, strongly modifying the learning resources, or even developing them from scratch.

In conclusion, I will try to evaluate both the European and the Israeli systems of Hebrew language teaching and testing, in view of contemporary assumptions of glottodidactics.
\end{abstract}

Hebrew language instruction within an organized system began along with the creation of the State of Israel. Since the first ulpanim were established, they were a model for Hebrew courses in the diaspora for many years. Unfortunately, the current goals, curricula, and teaching aids of Hebrew education seem to be irrelevant to students' needs, and to disregard the realities of the modern world.

In this paper, I wish to study several challenges and difficulties which might be faced by Hebrew teachers dealing with the rather burdensome task of teaching Hebrew in Europe based on slightly old-fashioned materials created in Israel, while being expected to adjust the methodology and assessment to meet European standards.

The necessity of creating new programs for foreign language teaching and adjusting them to the requirements of Common European Framework of Reference for Languages 
$(\mathrm{CEFRL})^{1}$ has resulted from implementing the Bologna Process in the Polish system of higher education. In 1999, ministers of education of twenty-nine European countries (including Poland) signed the Bologna Declaration - a document proposing a European Higher Education Area, within which students and graduates could move freely. ${ }^{2}$ The declaration includes tasks which ensure comparability in the standards and quality of higher-education qualifications, such as implementation of a unified system of studying (B.A., M.A.) and of European Credit Transfer System (ECTS) credit points promoting student and teaching staff mobility, cooperation among universities, as well as integrated teaching programmes, including foreign language instruction. Moreover, promoting the learning of many different foreign languages (including rare and exotic ones) as well as developing intercultural skills are among the objectives of European language policy. Since 2001, the Common European Framework of Reference for Languages has been used as a standard for teaching and grading language proficiency.

The CEFRL is intended to make it easier for educational institutions and employers to evaluate the language qualifications of candidates for education admission or employment. There are six levels of language competence: A1 (beginner), A2 (elementary), B1 (intermediate), B2 (upper-intermediate), C1 (advanced), and C2 (proficiency). The system is applicable to all the languages taught in Europe.

According to CEFRL, language competence should be taught and tested within four language skills: speaking, listening, reading, and writing.

Therefore, all language courses (and certainly all of those held by universities) should contain an element of assessment. That is why the issue of teaching Hebrew to students of Warsaw University, as well as writing certificates according to those new requirements, is discussed here.

Hebrew is taught at Warsaw University in its Hebrew Department, which is a part of the Faculty of Oriental Studies. B.A. graduates acquire their Hebrew command at advanced level (C1) after three years of intensive study - approximately twelve hours weekly, while M.A. graduates master it at C2 level. ${ }^{3}$

There are also regular Hebrew courses (four hours weekly) provided by the School of Eastern Languages at Warsaw University, at A1, A2, B1, B2, and B2+ levels. Besides Hebrew, more than thirty other languages like Arabic, Persian, Georgian or Romanian are taught. In almost all languages offered by Warsaw University certificate exams may be taken, in Hebrew at the A2, B1 and B2 levels. Moreover, every university student must pass a B2 certificate exam by the end of their B.A. studies, and some decide to take Hebrew. Certificate exams are provided by the School of Eastern Studies, prepared by university teachers and recognized by public administration institutions.

Israel, however, is not included in the Bologna Process. As a country of immigrants, it had to develop a well-organized and effective Hebrew tuition system. Thus, right after the creation of the State of Israel, the first Hebrew language schools, or ulpanim, as they are called in Hebrew, were formed. ${ }^{4}$ Ulpanim are to provide immigrants with basic language skills, as well as to present them with rudiments of Israeli culture and thus help

\footnotetext{
${ }^{1}$ Cf. https://www.coe.int/en/web/common-european-framework-reference-languages.

${ }^{2}$ Cf. https://www.eurashe.eu/library/modernising-phe/Bologna_1999_Bologna-Declaration.pdf.

3 Tomal 2007.

${ }^{4}$ Haramati 1999.
} 
them integrate in the society. Nowadays there are about eighty ulpanim in Israel which operate under the administration of the Ministry of Education, as well as private and university ulpanim. ${ }^{5}$ Hebrew is taught within six levels of command: from alef (beginner), bet (elementary), gimel (intermediate), dalet (upper intermediate), he (advanced) and waw (proficiency), which are roughly comparable with the European levels (A1-C2). Such division into levels operates mainly at universities; some other ulpanim work on 4-level system: A, B, C, and D. ${ }^{6}$

The State of Israel provides new immigrants with a 500-hour Hebrew course, which theoretically may enable them to achieve an intermediate/upper-intermediate level of Hebrew. Those immigrants who wish to study at university can (or even should) continue learning Hebrew. ${ }^{7}$

When it comes to assessment, there are two main Hebrew tests: Ptor and YAEL. Ptor is prepared and graded by university teachers of the Hebrew Language Schools of Hebrew or Tel Aviv University; while YAEL is written and administered by the National Institute for Testing and Evaluation. ${ }^{8}$ University candidates who are not native Hebrew speakers or, in other words, those who take the Psychometric Entrance Test (PET-Hapsichometri) in any language other than Hebrew are required to take YAEL or pass Ptor if they wish to study in Hebrew at the university. Students who have not passed Ptor or have not achieved the required score on the YAEL test must take Hebrew classes in addition to their normal academic courses during their first year of studies. ${ }^{9}$

Both YAEL and Ptor consist of three main parts:

1. Reading comprehension

2. Use of Hebrew

3. Writing. ${ }^{10}$

The Reading Comprehension task in Ptor is one long text with open questions, while in YAEL it consists of three short passages with multiple-choice answers.

The Use of Hebrew paper in both tests assesses one's command of grammar: word formation, inflection and syntax. In Ptor, this paper consists of two tasks: a wordformation text, where each word should be formed from its infinitive form given, and a multiple-choice text. In the latter, there are three options given, one of which should be selected. There is an optional sentence transformation task. It is an open task, with up to ten separate sentences, unrelated to each other, which are to be rewritten, sometimes using suggested words, sometimes without any suggestions. In YAEL, this paper consists of two main tasks: sentence completion using one of the four words given (three tasks) and transformation of sentences (multiple-choice tasks - one option to be selected out of four given).

\footnotetext{
5 See http://cms.education.gov.il/EducationCMS/UNITS/AdultEducation.

${ }^{6}$ More information available at: http://meyda.education.gov.il/files/adulteducation/2017/eigeretolpanimanglit.pdf.

7 For new immigrants from Ethiopia the number of hours has been doubled (http://cms.education.gov.il/ EducationCMS/Units/AdultEducation/HanchalatLashon/MIsgarotLimud/).

${ }^{8}$ https://nite.org.il/files/About-NITE/english.pdf.

9 http://info.huji.ac.il/overseas/heb/hebrew requirements.

${ }^{10}$ Cf.: www.wgalil.ac.il/files/HebrewExemption.pdf, http://www.nbn.org.il/aliyahpedia/education-ulpan /higher-education/yael-test/, https://www.nite.org.il/index.php/en/tests/yael.html.
} 
In the writing paper of $Y A E L$, students are asked to write a short essay (12-15 lines) on one topic given, while in Ptor they may choose one topic out of three given, and the length of the essay is to be 16 to 18 lines. Neither test limits the length of the essay according to the number of words.

When it comes to the score, Ptor is assessed by percentage, where $66 \%$ is a pass; and $Y A E L$ is scored in points, from 50 to 150 , and different universities have their own score requirements (for example, at Ben Gurion University the YAEL score 132 is equivalent to $66 \%$ in Ptor).

Although YAEL, when compared with Ptor, is a relatively modern exam (the latter has not changed a lot since the 1980s), the two tests do not differ much from each other. Both consist of the same three parts, but they check the same competences in a slightly different way: while YAEL is mostly structured on multiple-choice responses, in Ptor mostly open questions are asked.

Conversely, foreign language certificate exams which follow the CEFRL in general, as well as the Hebrew certificate exams at Warsaw University in particular, consist of five parts at each level:

1. Listening comprehension

2. Reading comprehension

3. Use of Hebrew

(Most of the above tasks are multiple-choice tasks.)

4. Writing paper ${ }^{11}$

5. Oral exam. ${ }^{12}$

When comparing the Israeli and European systems of assessment, we might observe that both YAEL and Ptor consist of three parts, actually testing only two language skills, while European certification exams are of five parts, testing four language skills. ${ }^{13}$

It is important to emphasize that the main idea of Communicative Language Teaching (CLT) or the Communicative Approach, which is today's most common and effective method of language instruction, is that the four basic language skills of reading, listening, speaking, and writing are developed and assessed. It is widely believed that learning according to CLT methodology enables students to understand authentic and useful listening and reading extracts, as well as react in authentic language and social situations.

As seen above, the Hebrew assessment system in Israel, not being among the most modern, needs to be altered, although some changes have been introduced recently. ${ }^{14}$ Similarly, Hebrew handbooks and other didactic tools require immediate reform. Those are mostly provided by top Israeli didactic institutions, such as Tel Aviv University or

11 At A2 level it is a short letter or email (30-50 words); B1 - instructions or report (70-80 words) and B2 - essay or report based on prompts (200-250 words).

12 At A2 level it is a short conversation on everyday issues. The B1 oral exam consists of testing language functions (like asking the way, ordering food at a restaurant or apologizing for being unprepared for classes); as well as describing a photograph. The B2 level oral exam requires students to express their opinion on a specific topic (usually based on a short fragment from a newspaper or magazine). Cf. (http://rada.wn.uw. edu.pl/pl/zasady-przystepowania-do-egzaminu/).

13 Although some elements of speaking part have been introduced into Hebrew exams in Israel (Aviad, Peretz 2003), there are no clear standards or exemplary tasks which might be accessed online or in exemplary written evaluation tests, Ptor or YAEL.

14 Rubinstein 2015. 
Hebrew University, and are used by teachers in Israel as well as by teachers of Hebrew abroad, and since the choice is limited, we all work with the same imperfect materials, which are old-fashioned (written in the 1990s or even the 1980s), and although some new books are being published, they repeat the same scheme of informative long texts (at all levels of education) and schematic grammar exercises, with a lack of authentic or close-to-authentic listening tasks, and no exemplary exams. However, a certain step towards modernity might be seen by the Ministry of Education's creation of a Moodle platform for ulpanim students. ${ }^{15}$

As seen above, Hebrew instructors, especially those who teach outside Israel, lack any of the professional aids that teachers of any foreign language are supported with: they work with handbooks without answer keys (even at the advanced levels); without professionally prepared lesson plans or teacher's guides; with recordings (if any) which are not authentic and lack relevant listening tasks; and they have no additional practice exercises (recommended online) or sample tests. Moreover, handbooks for more advanced students usually do not conform to any particular level and are written with no connection to each other.

To sum up, the Israeli curriculum of Hebrew teaching is fossilized; however effective for many years, it is nowadays a few steps behind new innovations in foreign language instruction. Therefore, Hebrew teachers who have to adjust their methodology to European standards are facing a difficult task, one made even more difficult due to a lack of teaching and assessment aids, most of which we need to create ourselves. ${ }^{16}$

Naturally, the question of whether the European system is to be regarded as the best one remains open. We may ask to what extent it tests real language skills and knowledge. ${ }^{17}$ We might question the idea of multiple-choice tests, the number of questions or the length of texts. ${ }^{18}$ However, as long as other languages are still being assessed based on four language skills, nothing better - more objective or wide-ranging - has thus far been worked out.

The lack of methodical and substantive support forces us teachers (most of us are not native speakers) to face difficult didactic challenges, like the necessity of drawing up new curricula, writing handbooks, and preparing other materials which are of good quality and compatible with the key requirements.

\section{BIBLIOGRAPHY}

\section{Sources}

Adamczyk, A., Dudzik-Rudkowska, M. (2015), "Mesochachim" - tochnit chadasha le-pituach meyumanut ha-dibur ["Let's Talk" - The New Programme of Conversation Course in Hebrew], Hed haulpan he-chadash 104: 56-63, at: http://meyda.education.gov.il/files/AdultEducation/hed_haulpan/ hed_104_angelika_martha.pdf, (Accessed: 16 August 2018).

${ }^{15}$ See: http://ae.lms.education.gov.il.

${ }^{16}$ In order to ease taking certificate exams for our students, as well as to facilitate their stay in Israel, we created a conversational program for intermediate-level learners that integrates four language skills, different forms of work and vocabulary arranged thematically (Adamczyk, Dudzik-Rudkowska 2015).

${ }^{17}$ Lewkowicz 2000.

${ }^{18}$ Goren, Roginsky, Yeret 2017. 
Aviad, R., Peretz, M. (2003), Ha-mahapecha ha-shketa be-hanchalat ha-lashon. Mivchanei haaracha be-siyum ha-ulpan [The Silent Revolution in Second Language Acquisition. Evaluation Tests at the End of Ulpan], in: Schlessinger, Y., Muchnik, M. (eds.), Kovetz mechkarim bi-mleut shloshim shana la-aguda ha-israelit le-balshanut shimushit [A Collection of Studies on the 30th Anniversary of the Israeli Association of Applied Linguistics], Jerusalem: 9-25.

Goren, S., Roginsky, D., Yeret, O. (2017), Haaracha ke-emtzayi le-kidum rechisha u-lemida shel safa nosefet [Evaluation as a Means of Promoting Foreign Language Acquisition], Hed ha-ulpan he-chadash 106: 55-72, at: http://meyda.education.gov.il/files/AdultEducation/hed_haulpan/ hed_106_rina_dina_orit.pdf(Accessed: 30 September 2018).

Haramati, S. (1999), Yovel la-ulpan: matzuy ve-ratzuy be-hanchalat ha-lashon [The Jubilee of Ulpan: Between the Reality and Needs in Hebrew Instruction], Hed ha-ulpan he-chadash 78: 6-20.

Lewkowicz, J.A. (2000), Authenticity in Language Testing: Some Outstanding Questions, Language Testing 17 (1): 43-64.

Rubinstein, S. (2015), Tochnit ha-limudim ha-chadasha be-hora at ha-lashon la-olim ba-agaf le-chinuch mewugarim [The New Language Teaching Programme for the Immigrants of the Adult Education Division], Hed ha-ulpan he-chadash 104: 7-12, at: http://meyda.education.gov.il/files/AdultEducation/hed_haulpan/hed_104_sara_rubinshtain_01.pdf(Accessed: 15 August 2018).

Tomal, M. (2007), Hebraistyka [Hebrew Studies], in: Popko, M. (ed.), 75 lat Instytutu Orientalistycznego Uniwersytetu Warszawskiego [75 Years of Faculty of Oriental Studies at Warsaw University], Warszawa: 63-72.

\section{Internet sources}

Bar-Ilan University. Sample Ptor Exam by Bar-Ilan University, at: www.wgalil.ac.il/files/HebrewExemption.pdf (Accessed: 28 September 2018).

Council of Europe. Common European Framework of Reference for Languages (CEFR) Official Website, at: https://www.coe.int/en/web/common-european-framework-reference-languages (Accessed: 25 September 2018).

European Ministers of Education (1999). The Bologna Declaration of June 1999, at: https://www. eurashe.eu/library/modernising-phe/Bologna_1999_Bologna-Declaration.pdf (Accessed: 25 September 2018).

Hebrew University of Jerusalem. Information on Hebrew Requirements at Hebrew University, at: info. huji.ac.il/overseas/heb/hebrew_requirements (Accessed: 28 September 2018).

Israel's Ministry of Education. Access to Moodle Platform for Ulpan Students, at: http://ae.lms.education.gov.il/ (Accessed: 23 November 2018).

Israel's Ministry of Education Official Website, Adult Education Division, at: http://cms.education.gov. il/EducationCMS/UNITS/AdultEducation (Accessed: 26 September 2018).

Israel's Ministry of Education, Adult Education Division, 2017. Letter to Ulpan Students, at: http:// meyda.education.gov.il/files/adulteducation/2017/eigeretolpanimanglit.pdf (Accessed: 26 September 2018).

National Institute's for Testing \& Evaluation of Israel Official Site, at: https://www.nite.org.il/index. php/en/tests/yael.html (Accessed: 28 September 2018).

Nefesh B'Nefesh Aliyah Official Site. Information on YAEL Test, at: http://www.nbn.org.il/aliyahpedia/ education-ulpan/higher-education/yael-test/ (Accessed: 28 September 2018).

Warsaw University. Certificate Exams Description, at: http://rada.wn.uw.edu.pl/pl/zasady-przystepowania-do-egzaminu/ (Accessed: 11 October 2018). 